\title{
FDI in Agriculture Sector in India with Special Reference to Academicians
}

\author{
Violet Glady
}

\begin{abstract}
Agriculture is the backbone of Indian economy. Nearly $70 \%$ of the society's livelihood is dependent on agriculture and account for $19 \%$ of India's GDP. To promote agriculture growth and to eliminate poverty, agricultural investment is mandate. National Savings is not able to meet the requirements of agricultural need for growth and development, thus global investment is inevitable to meet the investment requirement in agriculture. FDI in agriculture sector boosted up to Rs.611.28 Crore till December 2017. According to Indian scenario FDI up to $100 \%$ is allowed under the automatic route but subject to certain conditions mentioned in FDI policy.
\end{abstract}

FDI in agriculture sector is inevitable factor that drives agriculture to attain sustainability through foreign investment. Foreign investment in agriculture also enables farmer to implement new techniques in farming that increase the yield and production capacity along with fund inflow. Farmers in India undergoing many turbulence because of inadequate fund, unequal distribution of subsidies, exorbitant interest rates, obsolete technology, traditional farming pattern, inadequate crop rotation, monsoon failure and natural calamities. It is remarkable evidence that FDI in agriculture remove poverty, hunger, ensure growth and development. Agriculture investment can be segregated as private or public and foreign or domestic. Many researches have shown a positive result on going ahead with FDI in many sectors. It is notable that national savings are not able to match the growing need of the economy, thus FDI is inevitable factor to promote agriculture and all other sector.

This paper concentrates on the FDI inflow in Agriculture sector in India and the challenges faced by the sector in meeting the investment. Both primary and secondary data's are used to support this study. Primary data's are with special reference to academicians to analysis their overview of FDI in agriculture. Secondary data's are pooled from government source and websites. This paper enable to find out the need for FDI in agriculture and how to meet the challenges faced during the critical period.

Keywords : Foreign Direct Investment, Agriculture, poverty, academicians.

\section{INTRODUCTION}

India is typically an agricultural country with $70 \%$ of the society livelihood is dependent on agriculture. Agriculture sector in India account for nearly 14\% Gross Domestic Product (GDP). It is also notable that all sectors in India are dependent on agriculture for raw material. Government of India has stated that agriculture has grown prominently during the last decades by achieving highest ever food grain production of that rice production recorded 104.3 MT. It is an unavoidable fact that FDI in agriculture is essential for promoting agriculture that in turn reduces poverty and hunger.

Revised Manuscript Received on September 25, 2019

Mrs. Violet Glady, Assistant Professor,Department of Commerce, Stella Maris College-Chennai
Many researchers have shown that foreign investment in developing countries has favorable impact on economic growth and development. As far as India is concern foreign investments have not deep rooted in most of the rural areas. Agricultural investment can be segregated as public, private, foreign and domestic investment. It is an unavoidable fact that National savings are not able to meet the requirements and hence forth foreign investment is a source to bridge the investments and savings gaps.

\subsection{FDI in India}

The OECD (Organisation for Economic Cooperation and Development) defines FDI as "a category of investment that reflects the objective of establishing a lasting interest by a resident enterprise in one economy (direct investor) in an enterprise (direct investment enterprise) that is resident in an economy other than that of the direct investor. The lasting interest implies the existence of a long-term relationship between the direct investor and the direct investment enterprise and a significant degree of influence on the management of the enterprise. The direct or indirect ownership of 10\% or more of the voting power of an enterprise resident in one economy by an investor resident in another economy is evidence of such a relationship."

International Monetary Fund (IMF) has defined FDI as " $a$ category of cross border investment made by a resident in one economy. The flow of foreign capital is viewed as an instrument of growth and development".

According to Organization for Economic Co-operation and Development, an investment of $10 \%$ or above from overseas is marked as FDI. Foreign direct investment policy is regulated under the Foreign Exchange Management Act, 2000 governed by the Reserve Bank of India. Investment in India can be through Automatic route which does not require approval from RBI or under Government Route that require pre approval from concerned departments and ministries through single window - Foreign Investment Facilitation Portal (FIFP) governed by Department of Industrial Policy and Promotions (DIPP), under Ministry of Commerce and Industries.

FDI up to $100 \%$ is allowed under automatic route in specific area of agriculture and its allied sectors. Plantation sectors namely tea, coffee, cardamom, rubber, olive, and palm oil tree penetrates $100 \%$ FDI under automatic route. During the last 4 years i.e., 2013-2017 there was FDI inflow of $\$ 250.48$ million in agriculture. It is a clear picture that Foreign Direct Investment has boosted the agriculture sector in India.

1.2 Agriculture Sector - Specific Limits of Foreign Direct Investment Inflow in India 


\begin{tabular}{|c|c|c|}
\hline Sectors & FDI Cap/Equity & Entry Route \\
\hline $\begin{array}{l}\text { A. Agriculture } \\
1 . \quad \text { Floriculture, } \\
\text { Horticulture, } \\
\text { Development of } \\
\text { Seeds, Animal } \\
\text { Husbandry, } \\
\text { Pisciculture, and } \\
\text { Aquaculture, } \\
\text { Cultivation of } \\
\text { vegetables \& } \\
\text { mushrooms and } \\
\text { services related to } \\
\text { agro and allied } \\
\text { sectors. }\end{array}$ & $100 \%$ & Automatic \\
\hline $\begin{array}{lrr}2 . \quad \text { Tea } & \text { sector, } \\
\text { including } & \\
\text { plantation } & \\
\end{array}$ & $100 \%$ & FIPB \\
\hline $\begin{array}{l}\text { (FDI is not } \\
\text { allowed in any } \\
\text { other agricultural } \\
\text { sector /activity) }\end{array}$ & & \\
\hline
\end{tabular}

\subsection{Various Challenges for FDI Inflow in Indian Agriculture:}

\section{Lack of awareness}

Indian farmers are more conservative and out of reach of information on foreign direct investment. Most of the agrarian bulk is unaware of foreign investment in India. Problem concerning awareness can be removed by proper flow of information's to farmers through government and government nominated agencies or through advertisements.

\section{Lack of Technology and Knowledge}

Technology is the root of development. Adapting to digital innovation and developing in physical technology revamp the entire agrarian society. In India famer's till date continue traditional farming methods for cropping. Opening door for FDI helps in technological revolution in the field of agriculture. But still India is way behind the use of modern methods for farming because FDI is restricted in few areas of agriculture and allied activities.

\section{Lack of financial support and Loans}

Agriculture in India suffers from unavailability of formal finance especially to marginalized farmers. Financial drawback makes the farmers resist to various changes in technology. The major challenge for any sector is availability of smart finance. Agriculture can revolutionize only if foreign investment actively take part in financing process.

\section{Lack of regulatory requirements}

Due to vague and incompetent regulatory requirement the process gets delayed. Regulatory requirement in most of the cases are very rigid to changes. This highly concerns the growth of agriculture sector in India.

\section{Lack of co-ordination and alignment}

Most of the allied sectors are dependent on agriculture. Due to lack of co-ordination and alignment with foreign investment avenues it suffers from various drawbacks. Indian agriculture sector lack in interacting with foreign investors due to poor communication system and absence of technical knowledge among the farmers.

1.4 Countering Effect of FDI in agriculture sector in India:

1. Evolution in technology and new equipments

2. Sustainable growth and development

3. Eliminates hunger and Poverty

4. Establishes more investment avenues

5. Attainment of long term goals and objectives

- India's large agricultural subsidies are hampering productivity-enhancing investment.

- Overregulation of agriculture has increased costs, price risks and uncertainty.

- Government interventions in labour, land, and credit markets.

- Inadequate infrastructure and services

India's large agricultural subsidies are hampering productivity-enhancing investment.

- Overregulation of agriculture has increased costs, price risks and uncertainty.

- Government interventions in labour, land, and credit markets.

- Inadequate infrastructure and services.

- India's large agricultural subsidies are hampering productivity-enhancing investment.

- Overregulation of agriculture has increased costs, price risks and uncertainty.

- Government interventions in labour, land, and credit markets.

- Inadequate infrastructure and services.

\subsection{Objectives of the Study:}

The goal of this study was to identify evidence reflecting FDI in agriculture sector in India. The specific objectives of the study are:

1. To test the awareness level of samples on FDI in agriculture.

2. To study the challenges faced by agriculture sector in India

3. To analyse the barriers in implementation of strong FDI approach in agriculture sector in India.

4. To determine the countering effect of FDI in agriculture sector in India

\subsection{Hypothesis of the Study:}

The following hypothesis is formulated based on response retrieved from the respondents. The awareness level of respondent is tested along with other major variables such as challenges, barriers and effects of FDI in agriculture sector in India.

${ }^{1} \mathbf{H}_{0}$ : Gender and their awareness on FDI in Agriculture sector are independent.

${ }^{2} \mathbf{H}_{0}$ : There is no significant difference between the observed and expected value for the major challenges in agriculture in India

${ }^{3} \mathbf{H}_{0}$ : There is no significant difference between the observed and expected value for barriers

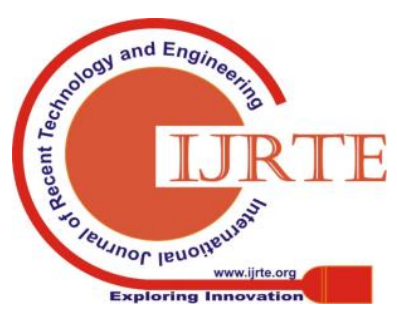


against implementation of strong FDI approach in agriculture

${ }^{4} \mathbf{H}_{\mathbf{0}}$ : There is no significant difference between the observed and expected value on countering effect of FDI in Agriculture sector in India

\section{REVIEW OF PAST STUDY}

2.1 Dr. Anjali Chaudhary (2016). "Role of FDI in the growth of Indian Agriculture Sector: A post reform study" has stated that FDI plays a dominant role in boosting the productivity by bridging the technological gap. In recent years, India is has stepping back from attracting more Foreign investors when compared to other developing countries like China, Hong Kong, Singapore, Thailand, Taiwan, Malaysia etc. Indian Policy makers should revamp their effort to attract more FDI in agriculture sector.

\subsection{Dr. ShobhitWadhwa\& Dr. SuchetaAroraWadhwa}

(2014). FDI in agriculture sector in India: status and challenges have stated that, fast-growing countries like India getting tuned with international know-hows and global marketing strategies are important to achieve growth and development. Increase trade between nations stimulates foreign direct investment. In tune with other sectors, Government of India is tirelessly working towards making agriculture a prominent investment avenue for global players. The agriculture sector have decreased in growth rate from $7.9 \%$ in $2010-11$ to $3.6 \%$ in 2011-2012 and declined further to $1.9 \%$ in $2012-2013$. To improve the worst situation Government of India started providing subsidies to small farmers but still the subsidies provided by Indian government is far less than developing countries. Theadvent of Food Security Act of India passed in the parliament has stimulated the need for high level of investment in agriculture sector.

2.3 Sandeep Kumar \&Kavita (2014). The research paper has stated that India with enormous population it is necessary to allow foreign investment to bring in technology and stable system that match with Indian culture. FDI is always preferred by developed countries instead of developing countries in order to boost up their business and productivity.

\section{RESEARCH METHODS AND MATERIALS}

The present study focuses on "the effects of FDI in agriculture sector in India". The parameter for this study is 100 samples collected from academicians in Tamilnadu. This study paper consist of four main hypothesis namely, ${ }^{1}$ the gender and their awareness about FDI in agriculture, ${ }^{2}$ the major challenges faced by agriculture sector in India ${ }^{3}$ the barriers to the implementation of strong FDI approach in agriculture and ${ }^{4}$ the countering effect of FDI in agriculture sector in India. The hypothetical condition is tested using Pearson Chi-Square to test the dependency level between two variables and One Sample Chi-Square test is adopted to test the goodness of fit under various conditions.

\section{ANALYSIS AND INFERENCE}

4.1 Cross tabulation - Gender and Awareness Level about FDI in agriculture Sector There is a positive growth trend of FDI inflows into India.

\begin{tabular}{|l|c|c|c|}
\hline & \multicolumn{2}{|l|}{$\begin{array}{c}\text { Are you aware of FDI in } \\
\text { agriculture sector in India }\end{array}$} & \multirow{2}{*}{ Total } \\
\cline { 1 - 3 } Gender & Fully Aware & Partially Aware & \\
\hline Male & 55 & 0 & 55 \\
\hline Female & 11 & 34 & 45 \\
\hline Total & 66 & 34 & 100 \\
\hline
\end{tabular}

The above table summarizes the general awareness level of the respondent about the FDI in agriculture sector in India. It clearly depicts that 55 out of 55 male populations is fully aware of the FDI operations in agriculture. Whereas, only 11 female samples is fully aware of the FDI in agriculture and remaining 34 female sample are partially aware of the operation of FDI in agriculture sector in India.

4.2 Pearson Chi-Square - Gender and Awareness Level about FDI in agriculture Sector

$\mathbf{H}_{\mathbf{0}}$ : Gender and their awareness on FDI in Agriculture sector are independent

\begin{tabular}{|l|r|r|r|r|r|}
\hline & Value & df & \multicolumn{1}{c|}{$\begin{array}{c}\text { Asymp. } \\
\text { Sig. } \\
\text { (2-sided) }\end{array}$} & $\begin{array}{c}\text { Exact } \\
\text { Sig. } \\
\text { (2-sided) }\end{array}$ & $\begin{array}{c}\text { Exact } \\
\text { Sig. } \\
(\text { 1-sided) }\end{array}$ \\
\hline $\begin{array}{l}\text { Pearson } \\
\text { Chi-Square }\end{array}$ & $62.963^{\mathrm{a}}$ & 1 & .000 & & \\
\hline $\begin{array}{l}\text { Continuity } \\
\text { Correction }\end{array}$ & 59.641 & 1 & .000 & & \\
\hline $\begin{array}{l}\text { Likelihood } \\
\text { Ratio }\end{array}$ & 78.154 & 1 & .000 & & .000 \\
\hline $\begin{array}{l}\text { Fisher's } \\
\text { Exact Test }\end{array}$ & & & & & .000 \\
\hline $\begin{array}{l}\text { Linear-by- } \\
\text { Linear } \\
\text { Association }\end{array}$ & 62.333 & 1 & .000 & & \\
\hline $\begin{array}{l}\text { N of Valid } \\
\text { Cases }\end{array}$ & 100 & & & & \\
\hline
\end{tabular}

Since the calculated Pearson Chi-Square Value is 62.963 and the associated significant value is .000 (less than 0.05 ), Hence $\mathrm{H}_{0}$ is rejected. The awareness level about the FDI in agriculture sector is there among the samples. Thus, the alternative hypothesis is accepted.

4.3 Chi-Square Test - The major challenges for FDI inflow in agriculture in India

$\mathbf{H}_{\mathbf{0}}$ : There is no significant difference between the observed and expected value for the major challenges in agriculture in India 
FDI in Agriculture Sector in India with Special Reference to Academicians

\begin{tabular}{|l|r|r|r|r|r|r|}
\hline & \multicolumn{7}{|c|}{ The major challenges for FDI inflow in agriculture in India } \\
\hline & $\begin{array}{c}\text { Lack of } \\
\text { Lack of } \\
\text { Awareness }\end{array}$ & $\begin{array}{c}\text { Technology } \\
\text { and } \\
\text { Knowledge }\end{array}$ & $\begin{array}{c}\text { Lack of } \\
\text { financial } \\
\text { support and } \\
\text { Loans }\end{array}$ & $\begin{array}{c}\text { Lack of } \\
\text { regulatory } \\
\text { requirements }\end{array}$ & $\begin{array}{c}\text { Lack of } \\
\text { co-ordination } \\
\text { and alignment }\end{array}$ & $\begin{array}{c}\text { Lack of } \\
\text { Crop } \\
\text { rotation }\end{array}$ \\
\hline Chi-Square & $10.240^{\mathrm{a}}$ & $98.240^{\mathrm{b}}$ & $64.220^{\mathrm{b}}$ & $54.380^{\mathrm{b}}$ & $33.300^{\mathrm{c}}$ & $37.580^{\mathrm{b}}$ \\
\hline df & 1 & 2 & 2 & 2 & 4 & 2 \\
\hline Asymp. Sig. & .001 & .000 & .000 & .000 & .000 & .000 \\
\hline
\end{tabular}

The above calculated NPAR Chi-Square value is 10.24 and associated significance is .001 (less than .05). Thus, $\mathrm{H}_{0}$ is rejected. Hence it is clear from the analysis that Lack of awareness is one factor contributing challenge for FDI inflow in agriculture sector in India.

The NPAR Chi-Square value for the second factor is 98.240 and the associated significance is .000 (less than .05) Thus, $\mathrm{H}_{0}$ is rejected. Hence it is clear that Lack of technology and knowledge is another factor contributing to challenge for FDI inflow in agriculture sector in India.

Similarly the other factors NPAR Chi-Square value is 64.220 , $54.380,33.300,37.580$ and the associated significance is .000 $(<.05)$. Thus, $\mathrm{H}_{0}$ is rejected for all the factors. Hence it is clearly projected that lack of financial support, lack of regulatory requirements, lack of co-ordination/alignment and lack of crop rotation are the remaining factors that contribute to the challenges for FDI inflow in India.

4.4 Chi-Square Test - Major Barriers against Implementation of Strong FDI Approach

$\mathbf{H}_{\mathbf{0}}$ : There is no significant difference between the observed and expected value for barriers against implementation of strong FDI approach in agriculture

\begin{tabular}{|l|r|r|r|r|}
\hline & \multicolumn{4}{|c|}{\begin{tabular}{|} 
Major Barriers Against Implementation of \\
Strong FDI Approach
\end{tabular}} \\
\hline & $\begin{array}{c}\text { Unavailabl } \\
\text { e } \\
\text { informatio } \\
\text { n }\end{array}$ & $\begin{array}{c}\text { Less } \\
\text { governm } \\
\text { ent } \\
\text { support }\end{array}$ & $\begin{array}{c}\text { Rigid } \\
\text { Policies } \\
\text { and } \\
\text { Norms }\end{array}$ & $\begin{array}{c}\text { poor } \\
\text { organizationa } \\
\text { l structure }\end{array}$ \\
\hline $\begin{array}{l}\text { Chi-Squar } \\
\text { e }\end{array}$ & $4.840^{\mathrm{a}}$ & $33.640^{\mathrm{a}}$ & $43.560^{\mathrm{a}}$ & \\
\hline df & 1 & 1 & & \\
\hline $\begin{array}{l}\text { Asymp. } \\
\text { Sig. }\end{array}$ & .028 & .000 & .000 & \\
\hline
\end{tabular}

The above NPAR Chi-Square value is 4.840, 33.640, 43.560 and 4.056 and the associated significance value is $.028, .000$, .000 and .044 (less than .05) Thus, $\mathrm{H}_{0}$ is rejected for all the factors. Hence the test clearly project that the following are the major barriers against implementation of strong FDI approach in India namely, Unavailable Information, Less governmental support, rigid policies and norms and poor organizational structure.
4.5 Chi-Square Test - Countering Effect of FDI in Agriculture Sector in India

$\mathbf{H}_{\mathbf{0}}$ : There is no significant difference between the observed and expected value on countering effect of FDI in Agriculture sector in India

\begin{tabular}{|l|l|r|r|r|r|}
\hline & \multicolumn{3}{|c|}{ Countering Effect of FDI in Agriculture Sector in India } \\
\hline $\begin{array}{c}\text { Evolution } \\
\text { in } \\
\text { technology } \\
\text { and new } \\
\text { equipment } \\
\text { s }\end{array}$ & $\begin{array}{c}\text { Sustainabl } \\
\text { e growth } \\
\text { and } \\
\text { developme } \\
\text { nt }\end{array}$ & $\begin{array}{c}\text { Eliminates } \\
\text { hunger } \\
\text { and } \\
\text { Poverty }\end{array}$ & $\begin{array}{c}\text { Establishes } \\
\text { more } \\
\text { investment } \\
\text { avenues }\end{array}$ & $\begin{array}{c}\text { Attainme } \\
\text { nt of long } \\
\text { term } \\
\text { goals and } \\
\text { objective } \\
\text { s }\end{array}$ \\
\hline $\begin{array}{l}\text { Chi-S } \\
\text { quare }\end{array}$ & $40.960^{\mathrm{a}}$ & $1.000^{\mathrm{a}}$ & $6.640^{\mathrm{b}}$ & $21.160^{\mathrm{a}}$ & $17.060^{\mathrm{c}}$ \\
\hline df & 1 & 1 & 3 & & \\
\hline $\begin{array}{l}\text { Asymp } \\
\text { Sig. }\end{array}$ & .000 & .317 & .084 & .000 & .000 \\
\hline
\end{tabular}

The above calculated NPAR Chi-Square value is 40.960 and associated significance is .000 (<.05) Thus, $\mathrm{H}_{0}$ is rejected. It is clearly projected from the analysis that allowing FDI in agriculture sector has countering effect on the evolution in technology and new equipments.

The second and third factor NPAR Chi-Square value is 1.000 and 6.640 and the associated significance is .317 and .084 (>.05) Thus, $\mathrm{H}_{0}$ is accepted. It clearly project that merely allowing FDI in limited areas of agriculture will not ensure overall growth and eliminates hunger and poverty.

The fourth and fifth factor NPAR Chi-Square value is 21.160 and 17.060 and the associated significance is .000 and .000 (<.05) Thus, $\mathrm{H}_{0}$ is rejected. It is clearly projected from the analysis that allowing FDI in agriculture sector has countering effect on achievement of long term goals and establishes investment avenues.

\section{CONCLUSION}

Agriculture being the important source for majority of the population, proper measures should be adopted by the government to ensure proper and steady fast flow of FDI in all agriculture based activities and allied activities. Limited route and restriction does not ensure sustainable growth and development. The various barriers to FDI should be eliminated by revamping the policies that are friendly and stable. India should move towards foreign investment in order to develop in digital and technological innovation in agriculture exclusively. It is also

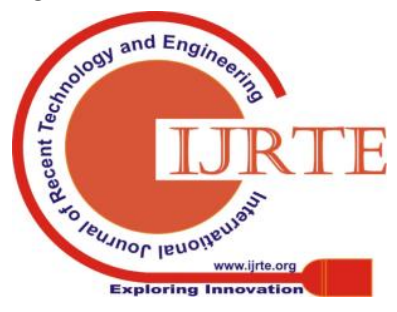


notable that the following changes have taken shape namely; FDI Loan facilitation through agriculture insurance Institution and NABARD has been extended and corpus of rural infrastructure fund is raised with these changes more financial linkage should be created to enhance the livelihood of the farmers.

\section{REFERENCES}

[1] Dr. Anjali Chaudhary (2016). Role of FDI in the growth of Indian Agriculture Sector: A post reform study, Global Journal of Finance and Management. ISSN 0975-6477 ,Vol. 8, No. 2. 2016

[2] Dwivedi P. and Badge J. (2013) Impact of FDI Inflow On Service Sector In India: An Empirical Analysis, International Journal of Management Research \& Business Strategy. ISSN 2319-345,Vol. 2, No. 3, July 2013

[3] Sandeep Kumar \&Kavita (2014).Indiastat.com, socio-economic voice.

[4] Dr. ShobhitWadhwa \& Dr. SuchetaAroraWadhwa. (2014) FDI in agriculture sector in India: status and challenges, Avon Publications, Book - Foreign Direct Investment,

[5] OECD. (2000). Glossary of Foreign Direct Investment Terms and Definitions. Available online: http://www.oecd.org/daf/inv/investmentpolicy/2487495.pdf 